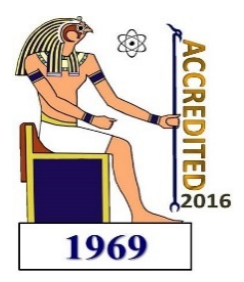

Delta Journal of Science

Available online at

https://djs.journals.ekb.eg/

Research Article

\title{
Subsurface Geological-Geotechnical 3D Modeling to Evaluate the Geohazard of the Alluvial Soils in Tanta Region, Egypt. GIS Approach
}

\author{
Alaa A. Masoud, Samir Z. Kamh and Sara R. Elgharib \\ Geology Department, Faculty of Science, Tanta University, 31527 Tanta Egypt
}

\begin{abstract}
Geological and geotechnical information from 159 borehole in-situ- and lab-based measured plasticity, unconfined compression, and consolidation parameters for alluvial clays have been analysed. For this analysis, 3D models was prepared using VOXLER 3 software package. The prime objective was to spatially model the geotechnical variability and to derive the loading factors along with recognition of the distinctive geotechnical patterns. Results have been presented for the alluvial soils of Tanta region, Egypt with the principal geotechnical hazards in the main eight districts were identified. Plasticity charts indicated that the soils are inorganic cohesive highly plastic clays. Geotechnical parameters showed wide ranges evidenced by their large standard deviations. Al-Mahata and Quhafa areas are characterized by high plasticity soils. Quahafa and beneath Al-Galaa street areas showed the largest unconfined compression strength. Largest over-consolidation ratio and compression index values were recorded in Al-Mahata and Al-Emary areas, respectively. High natural water content areas match well with those where water table is closer to the ground surface in Quhafa and Al-Emary areas. The results of the employed approach can help to establish geohazard zonation 3D maps with construction favorability for safe urban expansions.
\end{abstract}

Key words: Spatial variability; factor analysis; $k$-means clustering; Radial Basis Functions; sensitive clay shrinkage-swelling hazard; Tanta city; Egypt.

\section{Introduction:}

Managing environmental hazards for successful rational land use planning in rapidly growing cities with high anthropogenic pressure require in depth knowledge and accurate modeling of the spatial variability of the geological and geotechnical properties of the soils upon which cities were built (Kolat et al., 2006 and 2012 and Donghee et al., 2012). Geotechnical variability of soils naturally results from many disparate sources dependent on nexus of factors related to the geological and hydrogeological conditions, Climatology, and the human practices (Chang et al., 2005, Phien-wej et al., 2006 and Chrétien et al., 2007). Alluvial clays, in particular, commonly constitute significant hazard to constructions in terms of their ability to swell or to shrink and hence to volume change and are most likely over-consolidated (Dhowian et al., 1985) that result in land subsidence, differential settlements, and building collapse (Stavridakis, 2006, Hyndman and Hyndman, 2009). Changes to the volume and the hydrochemical contents of these clays are significant in the arid and semi-arid areas justifying their mutual analysis to disclose their geotechnical hazards. In these areas, the change of the soil water content is widely related to high evapotranspiration of vegetation that sometimes exceed four times the precipitation (FAO, 1998) brought about by local site changes such as leakage from water supply pipes or drains, or associated with a pattern of short periods of rainfall followed by long dry periods resulting in seasonal cycles of soil swelling and shrinkage (Cameron, 2006; Clayton et al. 2010). Unraveling the accurate spatial geotechnical and geological constraints of these clays and their spatial variability is therefore imperative for investigating the land suitability for construction and for land use management on the limited soil resource. This can play a decisive role to help efficiently prioritize areas with cost effective optimization of the construction times, efficient 
setting of hazard mitigation measures, and designing projects for safe extension with appropriate and reliable foundation system to compensate for geotechnical risks or over-costs e.g. (e.g. Parsons and Frost, 2002, Hack et al., 2006 and De Rienzo, et al., 2008). However, the geotechnical tests that are widely performed to understand the potential problems of soils can be time-consuming, expensive, and limited. This urges the use of a multidisciplinary approach that can integrate the multivariate statistical and geostatistical techniques in a Geographical Information Systems (GIS) environment .

The present research therefore aims at evaluating the integrated use of the multivariate statistical (Factor and cluster analyses) and the ordinary kriging for spatial variability mapping and analysis of the geotechnical characteristics of the alluvial clays. A special focus is devoted to characterizing the geotechnical hazards related to the fluctuating soil water conditions, i.e., water table, and the clay layer thickness, along with the soil's swelling and compressibility potentials and related geotechnical parameters. This is to enable prioritizing the land suitability of already settled areas and to determine if further precautions are needed for safer planning actions or remediation. Such study has been rarely addressed in Egypt and therefore the employed techniques have been applied to a case study area, the Gharbiya governorate, despite of the significant socio-economic impacts from the geotechnical hazards where the effects of catastrophic events are often amplified by the high anthropic pressure and the ineffective land management.

\section{Study area:}

Tanta is the capital city of the Gharbiya governorate (Egypt) located in the middle of the delta midway between the Rashid and Damietta branches of the Nile River (Fig. 1). Tanta district consists of the capital city, Tanta, 50 villages, and 200 small izba. It covers an area of about 331 $\mathrm{km} 2$ out of $1942 \mathrm{~km} 2$ of the Gharbiya governorate area. Tanta are built on the Holocene soils which made up of horizontal alluvial plain averaging $8.5 \mathrm{~m}$ above mean sea level ranging between $11 \mathrm{~m}$ at the south and $6 \mathrm{~m}$ at its northern part. Soils in the Nile delta are represented by the Holocene Bilqas formation, which forms from the top layer of brown silty clay, the bottom layer which consist of gray silty clay, constituting the agricultural soil of the delta. Bilqas consist of montmorillonite (Zaghloul et al., 1977), which is characterized by its high shrinking and swelling properties, The low permeability and low infiltration rate. Bilqas formation is underlain by Mit Ghamr Formation, which consist of a thick succession of unconsolidated sands and gravels which deposited under continental, lagoonal, fluviatile and beach environments. Tanta district is the fifth largest populated area in Egypt reached 438,000 (CAPMAS, 2012), increasing demand for housing, and urban management systems has increased the pressure of the local government to provide serviced land. Because there is not desert hinterland and there is limited horizontal expansion and the urban growth which has increased the capacity of the city. This lead to limited housing service, not enough facilities, deteriorating old residential neighborhoods, encroachment on agricultural land, and environmental pollution. Understand of the geotechnical properties of the clay soils to accurately identify and avoid future geotechnical hazards became a must. This could help proper selection and design of suitable surface and subsurface foundation systems by city planners that can allow efficient geohazard management planning. Such assessment has been rarely addressed in Egypt despite of the significant socio-economic problems raised recently from the geotechnical hazards.

\section{Data and methodology:}

\section{Geotechnical data analysis:}

The geotechnical data of the soils are collected from the schools and sewage construction projects carried out by the soil mechanics and foundation research laboratory, Faculty of Engineering, Cairo University and by the Arab Contractors company's Headquarter in Gharbiya. Geological investigations, in-situ, and lab-based geotechnical tests from 159 boreholes selected according to specific criteria were homogenized, classified, and archived in a GIS database thus far. Filtering criteria are based on selecting boreholes with a reliable location, a detailed measured stratigraphic logs with continuous coring vertical profile up to a depth of $20 \mathrm{~m}$ from the surface, and with complete in-situ and laboratory tests and statistically homogeneous with the whole data above 95\% confidence level. Geospatial referencing was carried out where the borehole location and ground surface elevations were field-determined using GARMIN GPS map 62SJ device.

The selected boreholes have a set of geotechnical information comprising the Atterberg consistency limits (Natural water content-NWC \%, Liquid limit-LL \%, Plastic limit- PL \%, Plasticity index-PI \%, and the Consistency index-Ci), Unconfined Compression Tests (Unconfined Compression Strength-UCS, and Dry Density-DD), Consolidation Tests (Initial Void Ratio-IVR, Effective Overburden Pressure-EOP, Over Consolidation Ratio-OCR, Pre-consolidation Pressure- PP, and the Compression Index- Cc). The depth to water table and the ground surface elevation was also included in the analysis. Uni-variate and bi-variate statistics are applied to derive descriptive summary statistics of and key relationships using the Pearson's correlation coefficients of and among the studied variables. A 3D database was built and visualized using VOXLER 3 software package. This database comprise all the selected data for the city, adopting a procedure developed to predict more reliably the spatial geotechnical information and their layers. This database can enables users to examine the geotechnical data referenced by spatial coordinates and to export these data in the form of an ASCII or a DXF file, which can be easily imported to other numerical tools .

\section{Consistency limit:}

The consistency limits are water contents at certain critical stages that define the transitions between the liquid, plastic, and brittle solid stages of a fine-grained cohesive soil. These limits are useful indicators of clay 
behavior where certain types of clayey soils expand when they are wetted and shrink when dried and are mainly used for plasticity classification based on the relative position of the samples to the A-line on the Casagrande graph (Casagrande, 1932). Swelling properties are rarely employed in the course of routine site investigations in Egypt because few engineering applications have a perceived requirement for these data for design or construction. Reliance has to be alternatively, placed on estimates based on index parameters, such as liquid limit (LL), plasticity index (PI), and density (Reeve et al., 1980, Holtz and Kovacs, 1981 and Oloo et al., 1987). LL and PI are broadly used for evaluating the swelling potential of soil (Thomas et al., 2000).

\section{Consolidation characteristics:}

Soil consolidation is the volume reduction due to the drainage of pore water that a laterally confined soil specimen undergoes when subjected to different vertical pressures. Tests are performed mainly to determine the magnitude of the maximum past pre-consolidation pressure (PP), present effective overburden pressure (EOP) used to calculate the over consolidation ratio (OCR) defined as the ratio of PP to EOP. OCR indicates that soils are normally consolidated, over consolidated or under consolidated. The soil becomes over consolidated if EOP is less than PP. Change in volume occurs due to the rearrangement of the solids in the initial voids defined as the initial void ratio (IVR), the ratio between voids to solids in soils. The compression index $(\mathrm{Cc})$ indicates the deformation characteristic of the over consolidated soils and their compressibility (Larson et al., 1980), the higher the $\mathrm{Cc}$ the greater the deformation that will develop for the same change in stress. Three consolidation parameters, IVR, OCR, and Cc are commonly interrelated (Gunduz and Arman, 2007) and deemed necessary to spatially characterize the compressibility of the studied clays.

\section{Results and discussion:}

\section{Geotechnical properties:}

The geotechnical parameters (Table 1) showed wide ranges: Liquid limit (0.81-105\%), Plastic limit (20 -34 \%), Plasticity index (18-78.6\%), depth to water $(1.19-6.4 \mathrm{~m})$, unconfined compression strength $(0.87-3.17 \mathrm{~kg} / \mathrm{cm} 2)$, compression index (0.14-0.33), and over-consolidation ratio (1.55-5.58). Such wide ranges suggest that multiple sources and/or complex geological/hydrogeological processes affect the spatial variability of the geotechnical properties. The Pearson's correlation coefficient (r) discloses the degree of dependency of one variable to the other. From matrix plot, strong $(\mathrm{r} \geq 0.5)$, moderate $(\mathrm{r}<0.5$ to 0.3$)$ and low $(\mathrm{r}<0.3)$ correlation between selected variables was set. Coefficients were strong within the plasticity, consolidation, and the unconfined compression tests, arranged in decreasing order of correlation strength (Table 2). Generally, correlation was moderate to low between the tests. LL strongly positively correlated $(\mathrm{r}=$ 0.84) with both the PI and Cs. The compression index (Cc) showed moderate correlation with the IVR $(r=0.42)$ and NWC $(\mathrm{r}=0.36)$.

\section{Plasticity characteristics:}

Plasticity chart Casagrande (1932) showed that the soils are inorganic cohesive clays of high plasticity $(\mathrm{CH})$ and hence with high capability of volume changes. All samples are plotted above the A-line, except five samples are located in the inorganic clays of moderate plasticity (Fig. 2). The soils tend to show a general increase in PI which can be best determined linearly at $\mathrm{R}^{2}=0.95$ against LL. Plasticity 3D models showed largest values (LL, PL, PI, and Ci) at Al-Mahata with some local highs marked Quhafa area (Fig. 3).

\section{Thickness of the silty clay layer:}

The brown silty clay layer is generally thinner in the south, reaching a maximum of $10 \mathrm{~m}$, and increases gradually northwards to reach its maximum of $12 \mathrm{~m}$ thickness sometime intercalated with medium sands (Fig. 4). Grey silty clay layer lying below the brown silty clay reaches $3 \mathrm{~m}$ south and gradually disappears northwards. Medium sands dominate below the grey silty clay with an average thickness of $10 \mathrm{~m}$.

\section{Soil saturation-related hazards:}

The depth to water is one of the main factors affecting the stability of foundation and pose serious risks to residential development (Marache, et al., 2009, El May et al., 2010 and Kolat et al., 2012) since it affects greatly the nature water content. The static water level varied from $0.5 \mathrm{~m}$ to $6.4 \mathrm{~m}$ below the ground surface (Table $1 \&$ Fig. 5). The NWC 3D model (Fig. 6) shows high water content in areas located where the water table is close to the ground surface and vice versa. The water table and hence its flow direction is affected by the topography. When water table approaches the surface, it raises the risks of the cyclic seasonal evaporation that contributes to the creation of waterlogging conditions favorable to the occurrence of swelling of clays and enhances the soil salinity and hence the severity of damages to the structures resulting from the corrosion potential and ameliorates the construction favorability. On a similar alluvial deposits in Tunisia, areas where water table approached the surface (0-5 m), assigned the least favorability for construction (El May et al., 2010). Similarly, areas where water table coincided with the surface in Turkey were not suitable for settlement (Kolat et al., 2012).

\section{Swelling potentials and compression strength:}

The unconfined compressive strength (UCS) determines the bearing capacity of foundations that is related to the consistency of the soil where the harder the soil the higher the UCS and the shear strength. Successful stabilization of expansive soils greatly rely, therefore, on increasing the compressive strength by reducing the plasticity index and hence the swelling potential (e.g., ASTM, 2005). The unconfined compression strength correlate well with swelling potential (Masoud, 2015). Generally, UCS values increase upwards and areas having highest UCS $(4.8 \mathrm{~kg} / \mathrm{cm} 2)$ show low swelling potential located beneath Quahafa and Al-Galaa street (Fig. 7).

\section{Consolidation and compressibility potentials:}


The studied soils are over consolidated attained OCR between 1.55 and 5.58. The compression index (Cc) ranged between 0.14 and 0.33 . 3D models of the consolidation parameters clarified regional conformable zones of IVR, OCR, and Cc (Fig. 8). Compression index, $\mathrm{Cc}$, relies moderately on the IVR $(\mathrm{r}=0.42)$. High IVR zones characterize the districts of Quhafa and Al-Emary areas. Largest OCR marks Al-Mahata area. Zones of highest compressibility potentials evidenced by the highest compression index $(\mathrm{Cc})$ occurred in Al-Emary confirming the lowest swelling potentials. IVR reaches a maximum of 97\% in Quhafa and Al-Emary areas. Cc showed highest values of 0.29 in Al-Emary area OCR reaches its maximum of 5.5 in Al-Mahata area. Highest PP and OCR mark Al-Mahata area. The effective overburden pressure ranged between 0.44-1.21 where the largest EOP characterizes Al-Dawaween area. Being one of the oldest areas in Tanta city, Al-Mahata area showed the largest preconsolidation pressure.

\section{Conclusions:}

The complex subsurface of Tanta City has shown the need for 3D geological-geotechnical modeling to represent the subsurface spatial behavior of the ground for supporting subsoil future planning. 3D modeling is expected to improve the planning and storing geologicalgeotechnical information data in databases with 3D capabilities is of great importance in all stages of a construction. This also helps in preparation of the geotechnical zoning maps describing the suitability of a safe construction. This is the first attempt to address the geotechnical hazards of soils in cities in a GIS framework in Egypt. The results of this research can enable city planners to prioritize areas with risks or over-costs for civil engineering projects. Specifically, the results can be used by geotechnicians, urban planners or civil engineers for (a) evaluation and planning of urban areas according to the engineering conditions and the geohazard zones; (b) selection of engineering geological investigations areas of construction; (c) selection of a suitable foundation type and construction design; and (d) suppose changing of the engineering geological conditions and prediction of hazardous geological phenomena.

The analysis of these geostatistical models could allow us to define areas as being sensitive to the clay shrinkageswelling hazard for example. The soils are inorganic clays of high plasticity $(\mathrm{CH})$ and with high capability of volume changes which lead to ground movements. In order to reduce ground movements sourced from underlying swelling soils, one of the measures should be taken into consideration when the light structures are built such as replacement or partial replacement of expansive soils with non-expansive soils, lime stabilization can minimize the amount of shrinkage and swelling, and the amount of expansive soils can also be reduced significantly, if they are compacted at low densities and high moisture content.

\section{References}

Delta J. Sci. 2016; Vol. : ()
American Society for Testing and Materials Annual Book of ASTM Standards (ASTM) (2005): Volume 04.08, Soil and Rock (I): D 420 -D 5611 and Volume 04.09, Soil and Rock (II): D 5714-latest. West Conshohocken, Pennsylvania.

Cameron D.A., (2006): The Role of Vegetation in Stabilizing Highly Plastic Clay Subgrades. Proc. Of Railway Foundations, RailFound 06, (Ghataora G.S. and Burrow M.P.N. eds), Birmingham, Sept., 165-186.

Casagrande, A., (1932): Research on the Atterberg limits of soils. Public Roads 13 (8), 121-136.

Central Agency for Public Mobilization and Statistics, Egypt (CAPMAS) (2012): http://www.capmas.gov.eg/

Chang, M., Chiu, Y., Lin, S., Ke T., 2005. Preliminary study on the 2003 slope failure in Woo-wan-chai Area, Mt. Ali Road, Taiwan. Engineering Geology 80: 93114 .

Chrétien, M., Fabre, R., Denis, A., Marache, A. (2007): Recherche des paramètres d'identification géotechnique optimaux pour une classification des sols sensibles au retrait gonflement. Revue Française de Géotechnique 120-121: 91-106.

Clayton, C.R.I., Xu, M., Whiter, J.T., Ham, A., Rust, M. (2010): Stresses in cast-iron pipes due to seasonal shrink-swell of clay soils. Proceeding of the Institution of Civil Engineers: Water Management, 163 (WM3): 157-162.

De Rienzo, F., Oreste, P., Pelizza, S. (2008): Subsurface geological-geotechnical modelling to sustain underground civil planning. Engineering Geology 96: 187-204

Dhowian, A., Ruwiah, I., Erol, A. (1985): The distribution and evaluation of expansive soils in Saudi Arabia. In: Proceedings of the Second Saudi Engineering Conference, vol. 4. King Fahd University of Petroleum and Minerals, Dhahran, 1969-1990.

Donghee K., Kyu-Sun K., Seongkwon K., Youngmin C., Woojin L. (2012): Assessment of geotechnical variability of Songdo silty clay. Engineering Geology 133-134: 1-8.

El May, M., Dlala, M., Chenini, I., 2010. Urban geological mapping: Geotechnical data analysis for rational development planning. Engineering Geology 116 (1-2): 129-138 .

FAO (1998): Evapotranspiración del cultivo.Guíaspara la determinación de los requerimientos de agua de los cultivos.Estudio FAO riego y drenaje 5.Report, Food and Agriculture Organization (FAO) of the United Nation, Rome, Italy.

Gunduz, Z. Arman, H. (2007): Possible Relationships Between Compression and Recompression Indices of a Low-Plasticity Clayey Soil. Arabian Journal for Science and Engineering 32 (2B): 179-190.

Hack, R., Orlic, B., Ozmutlu, S., Zhu, S., Rengers, N. (2006): Three and more dimensional modelling in geoengineering. Bulletin of Engineering Geology and the Environment 65: 143-153 .

Holtz, R.D., Kovacs, W.D. (1981): An Introduction to Geotechnical Engineering, Prentice-Hall, Inc, Eaglewood Cliffs, New Jersey. 
Hyndman, D., Hyndman, D. (2009): Natural Hazards and Disasters. Brooks/Cole, Cengage Learning, California.

Kolat, Ç, Doyuran, V., Can Ayday, C., Lütfi Süzen, M. (2006): Preparation of a geotechnical microzonation model using Geographical Information Systems based on Multicriteria Decision Analysis. Engineering Geology 87 (3-4): 241-255.

Kolat, Ç, Ulusay,R., Lütfi Süzen, M. (2012): Development of geotechnical microzonation model for Yenisehir (Bursa, Turkey) located at a seismically active region. Engineering Geology 127: 36-53.

Larson, W.E., S.C. Gupta, R.A. (1980): Useche. Compression of agricultural soils from eight soil orders. Soil Sci. Soc. Am. J. 44: 450-457.

Marache, A., Breysse, D., Piette, C., Thierry, P. (2009) Geotechnical modeling at the city scale using statistical and geostatistical tools: The Pessac case (France). Engineering Geology 107(3-4): 67-76.

Masoud, A. A. (2015): Geotechnical evaluation of the alluvial soils for urban land management zonation in Gharbiya governorate, Egypt. Journal of African Earth Sciences 101: 360-374.

Oloo, S., Schreiner, H.D., Burland, J.B. (1987): Identification and classification of expansive soils. 6th International Conference on Expansive Soils,
December 1987, New Delhi, India, Imperial College of Science and Technology, London, 23-29.

Parsons, R. L., Frost, J.D. (2002): Evaluating site investigation quality using GIS and geostatistics. Journal of Geotechnical and Geoenvironmental Engineering 128 (6): 451-461.

Phien-wej, N., Giao, P.H., Nutalaya, P. (2006): Land subsidence in Bangkok, Thailand. Engineering Geology 82: 187-201 .

Reeve, M.J., Hall, D.G.M., and Bullock, P. (1980): The effect of soil composition and environmental factors on the shrinkage of some clayey British soils. Journal of Soil Science 31: 429-442.

Stavridakis, E.I. (2006): Assessment of anisotropic behaviour of swelling soils on ground and construction work. In: Al-Rawas, A.A. and Goosen, M.F.A. (Eds). Expansive soils: Recent advances in characterization and treatment. Taylor and Francis, London.

Thomas P.J., Baker J.C., and Zelazny L.W. (2000): An expansive soil index for predicting shrink-swell potential. Soil Science Society of America Journal 64: 268-274.

Zaghloul, Z.M., Taha, A.A., Hegab, O., El Fawal, F. (1977): The Neogene-Quaternary sedimentary basins of the Nile Delta. Egyptian Journal of Geology 21 (1): $1-19$.

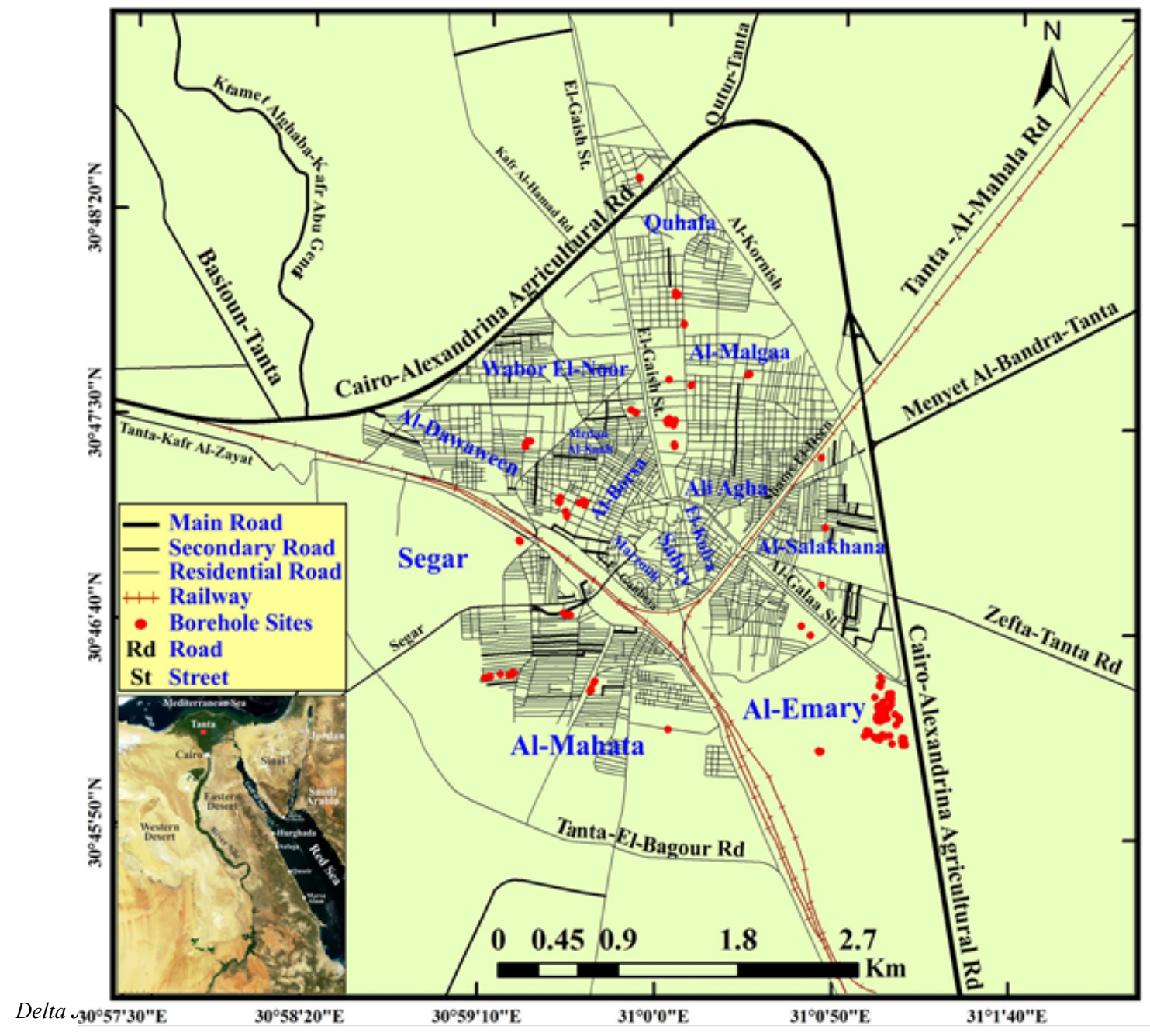




\begin{tabular}{lccccc}
\hline Parameter & Mean & Standard Deviation & Min. & Max. & Count \\
\hline Thickness (m) & 8.67 & 3.44 & 2.1 & 15 & 154 \\
Elevation (m) & 11.91 & 2.97 & 6 & 17 & 159 \\
Natural Water Content \% & 31.37 & 5.82 & 0 & 45.15 & 105 \\
Liquid Limit \% & 77.71 & 15.33 & 0.81 & 105 & 107 \\
Plastic Limit \% & 29.02 & 3.38 & 20 & 34 & 107 \\
Plasticity Index & 49.43 & 11.39 & 18 & 78.6 & 107 \\
Consistency Index & 0.93 & 0.16 & 0 & 1.23 & 105 \\
Unconfined compression strength (kg/cm $\left.{ }^{2}\right)$ & 1.55 & 0.51 & 0.87 & 3.17 & 51 \\
Initial Void Ratio-IVR & 0.90 & 0.08 & 0.6 & 0.99 & 31 \\
Compression Index-Cc & 0.23 & 0.05 & 0.14 & 0.33 & 31 \\
Pre-Consolidation Pressure-PP & 1.88 & 0.40 & 1.3 & 2.9 & 31 \\
Effective Overburden Pressure-EOP & 0.63 & 0.15 & 0.44 & 1.21 & 31 \\
Over Consolidation Ratio-OCR & 3.11 & 0.85 & 1.55 & 5.58 & 31 \\
GWI & 3.06 & 1.14 & 1.19 & 6.4 & 155 \\
GWF & 2.43 & 1.17 & 0.5 & 5.3 & 155 \\
\hline
\end{tabular}

Fig. (1): Location map of the study area.

Table (1): Descriptive statistics of the geotechnical parameters in Tanta City.

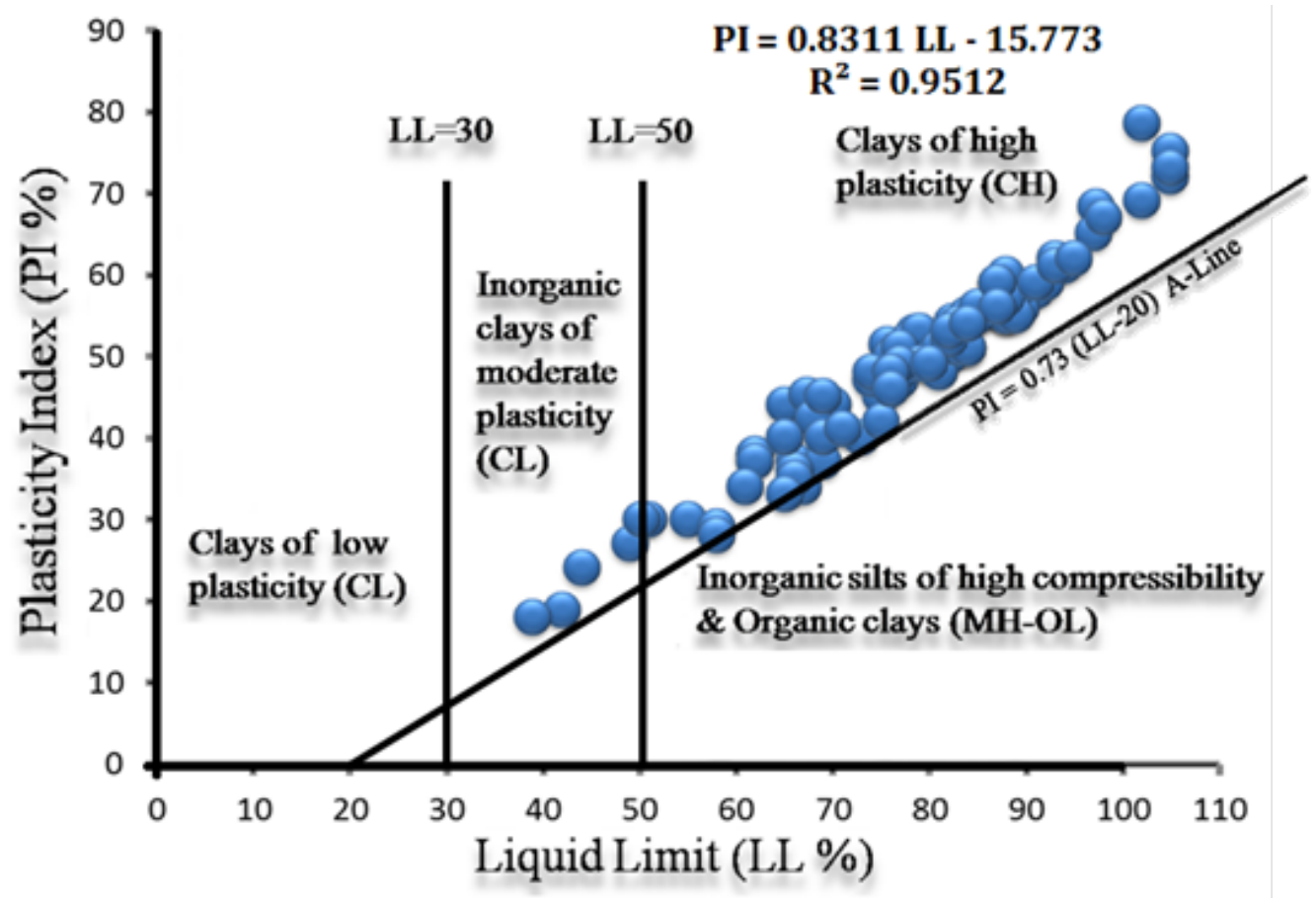


Fig. (2): Plasticity chart for the cohesive soils in Tanta City.

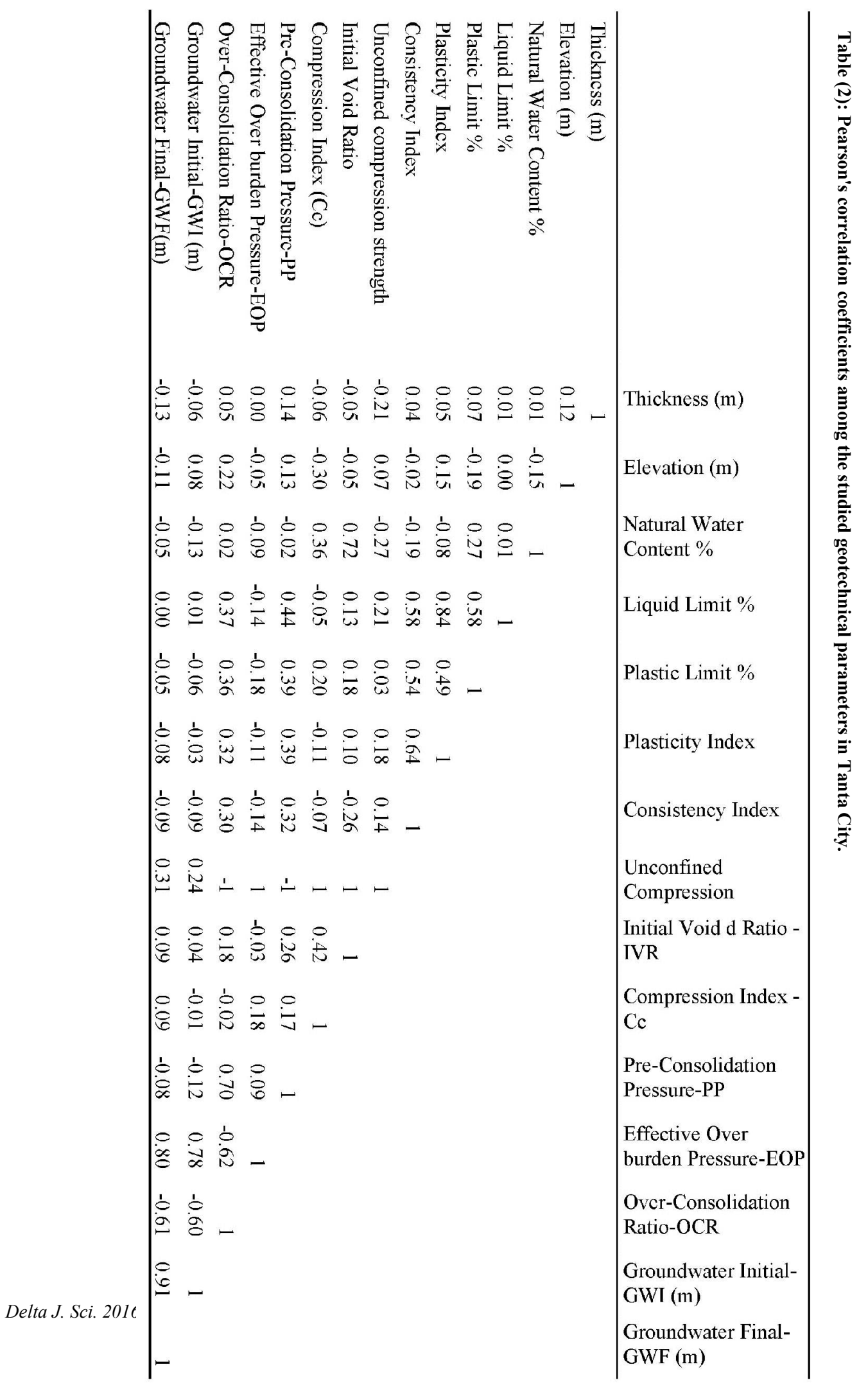




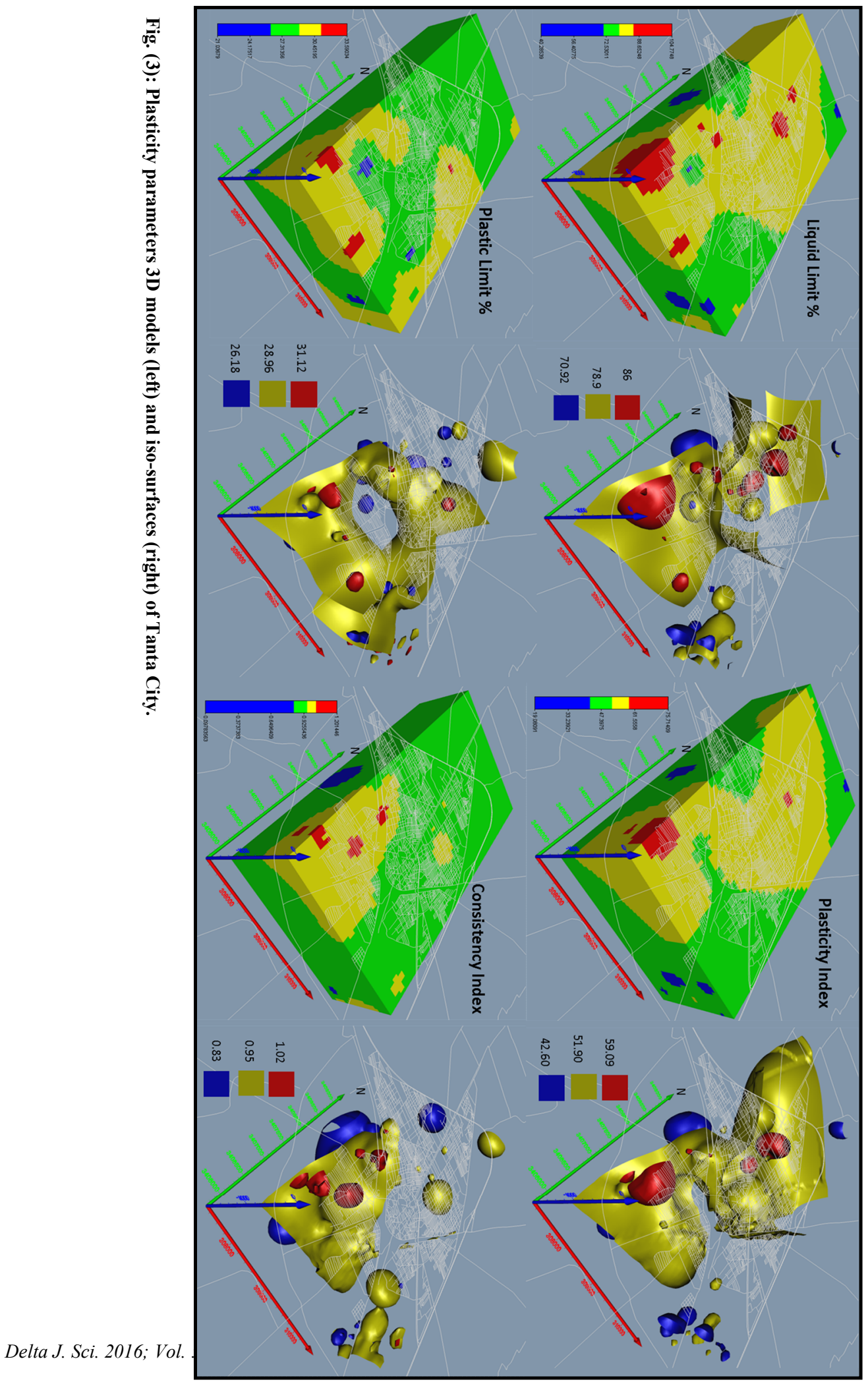




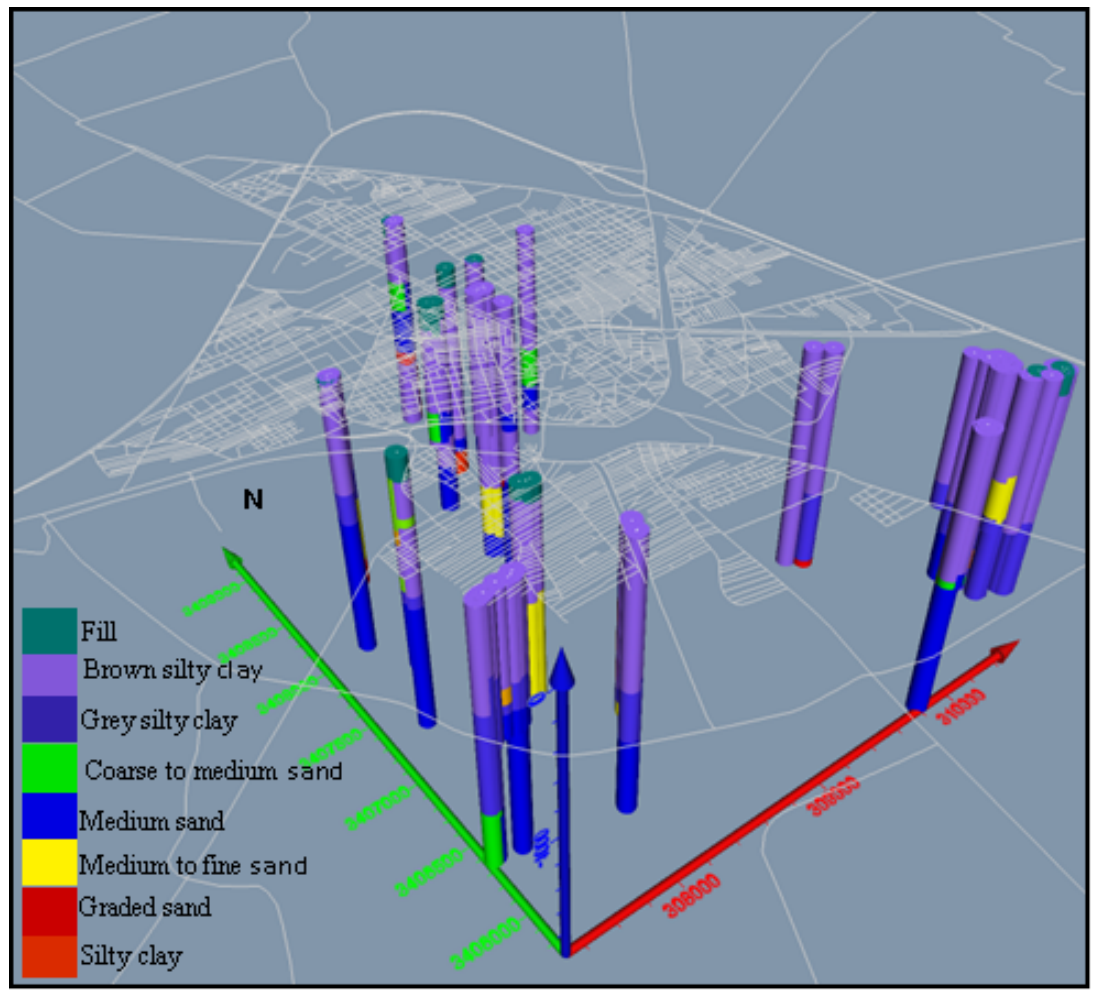

Fig. (4): Location of boreholes with soil composition in Tanta City.

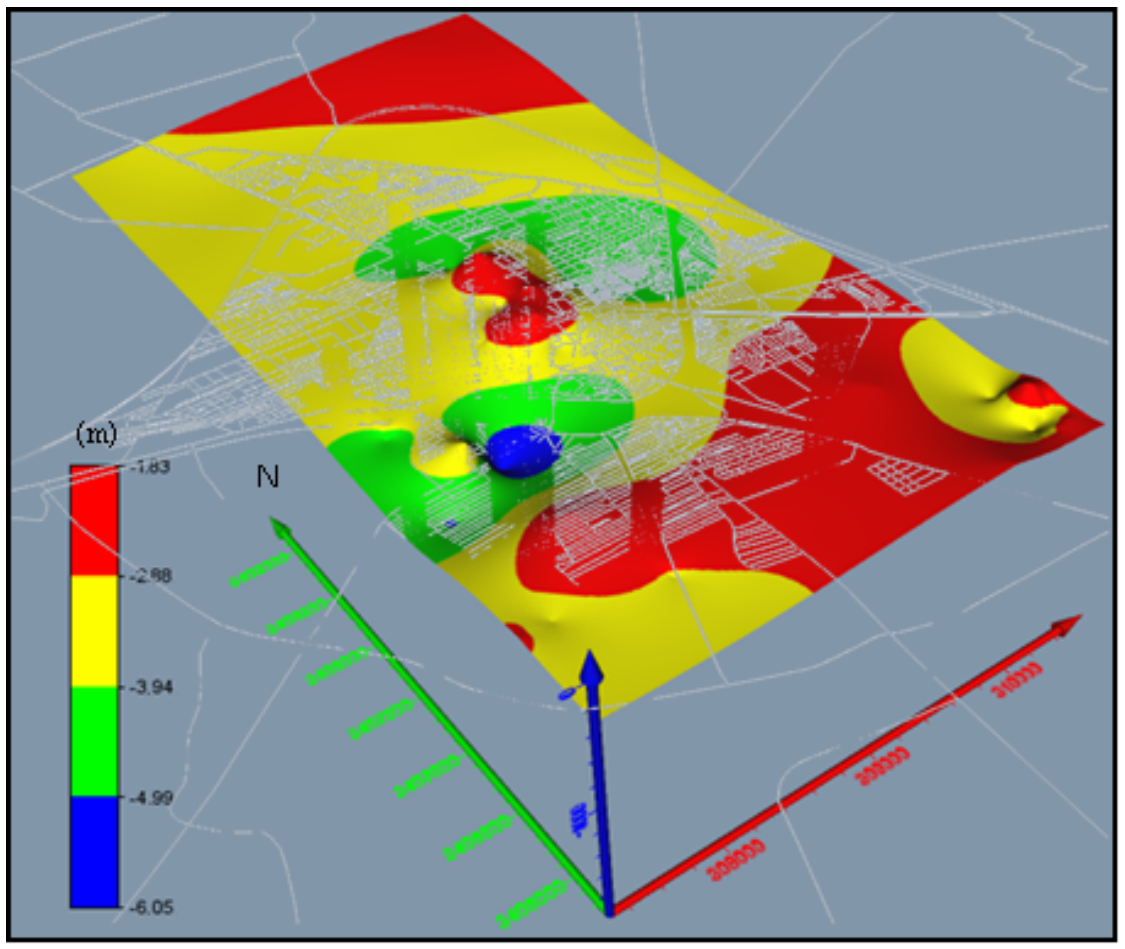

Delta J. Sci. 2016; Vol. : () 
Fig. (5): Water table 3D map of Tanta City.

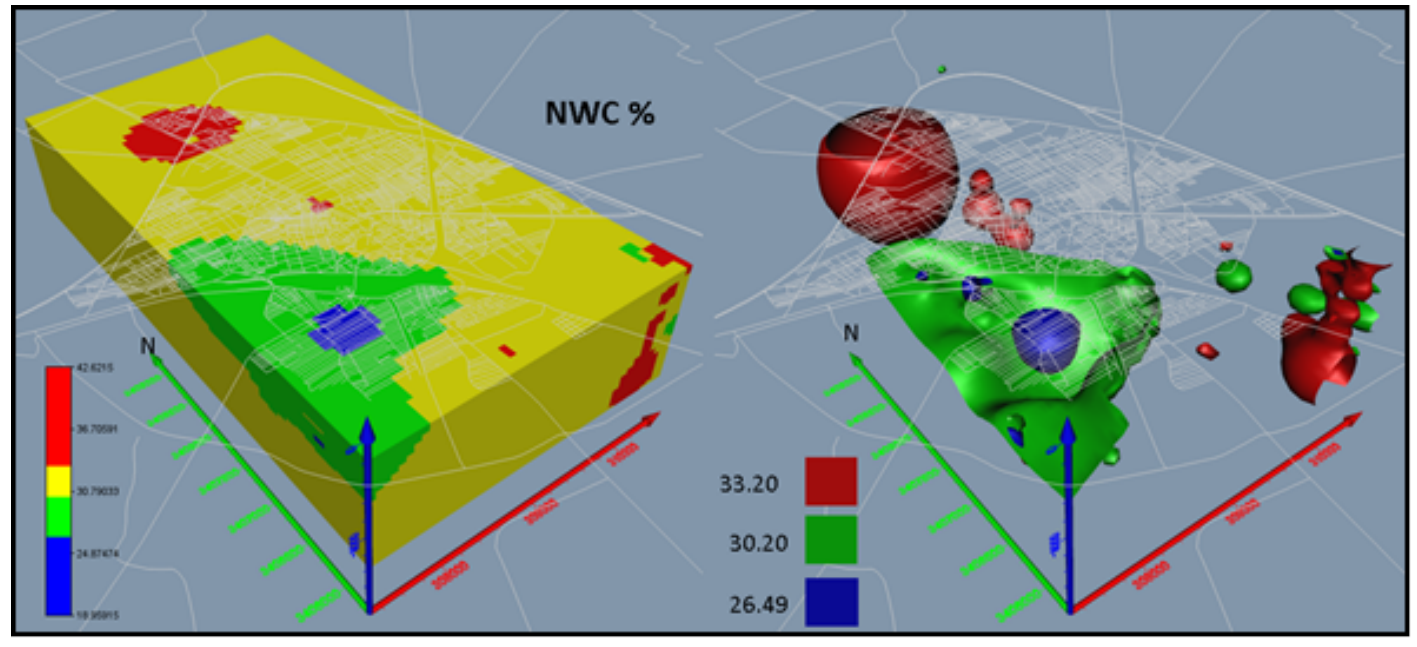

Fig. (6): Natural water content (NWC \%) 3D model (left) and iso-surfaces (right) of Tanta City.

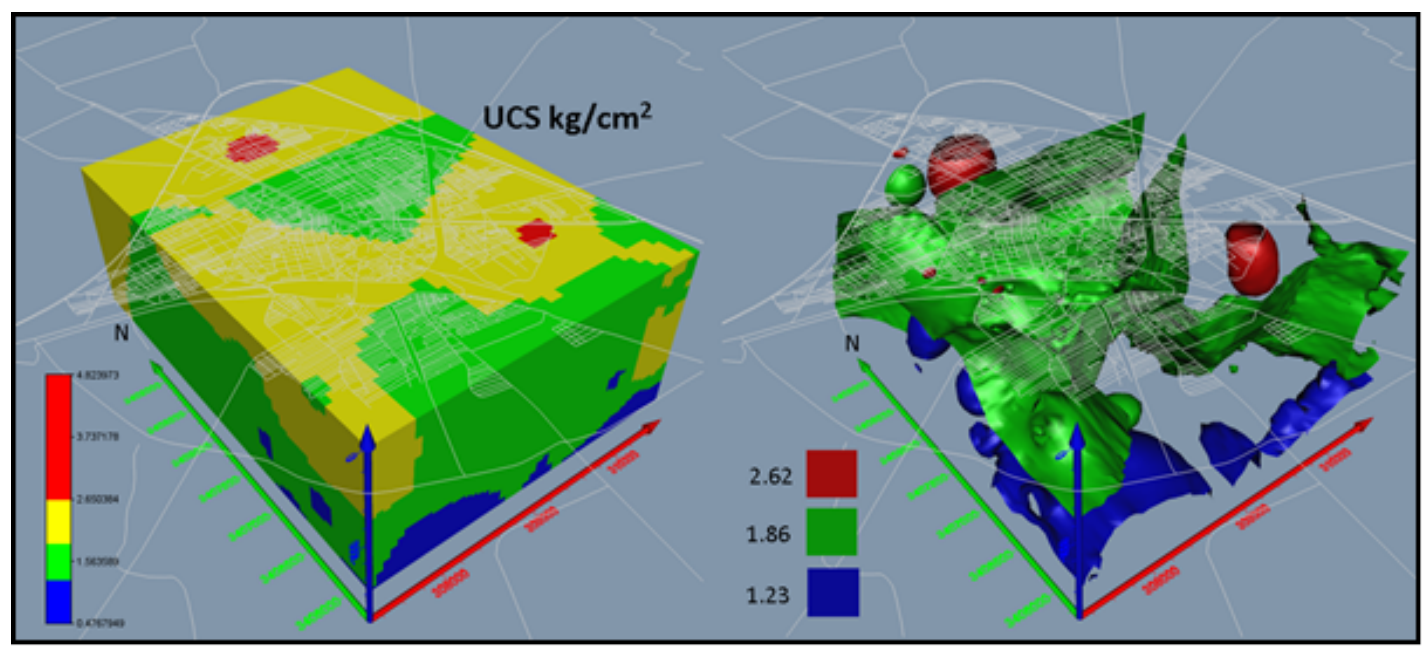

Fig. (7): Unconfined compression strength 3D model (left) and iso-surfaces (right) of Tanta City. 


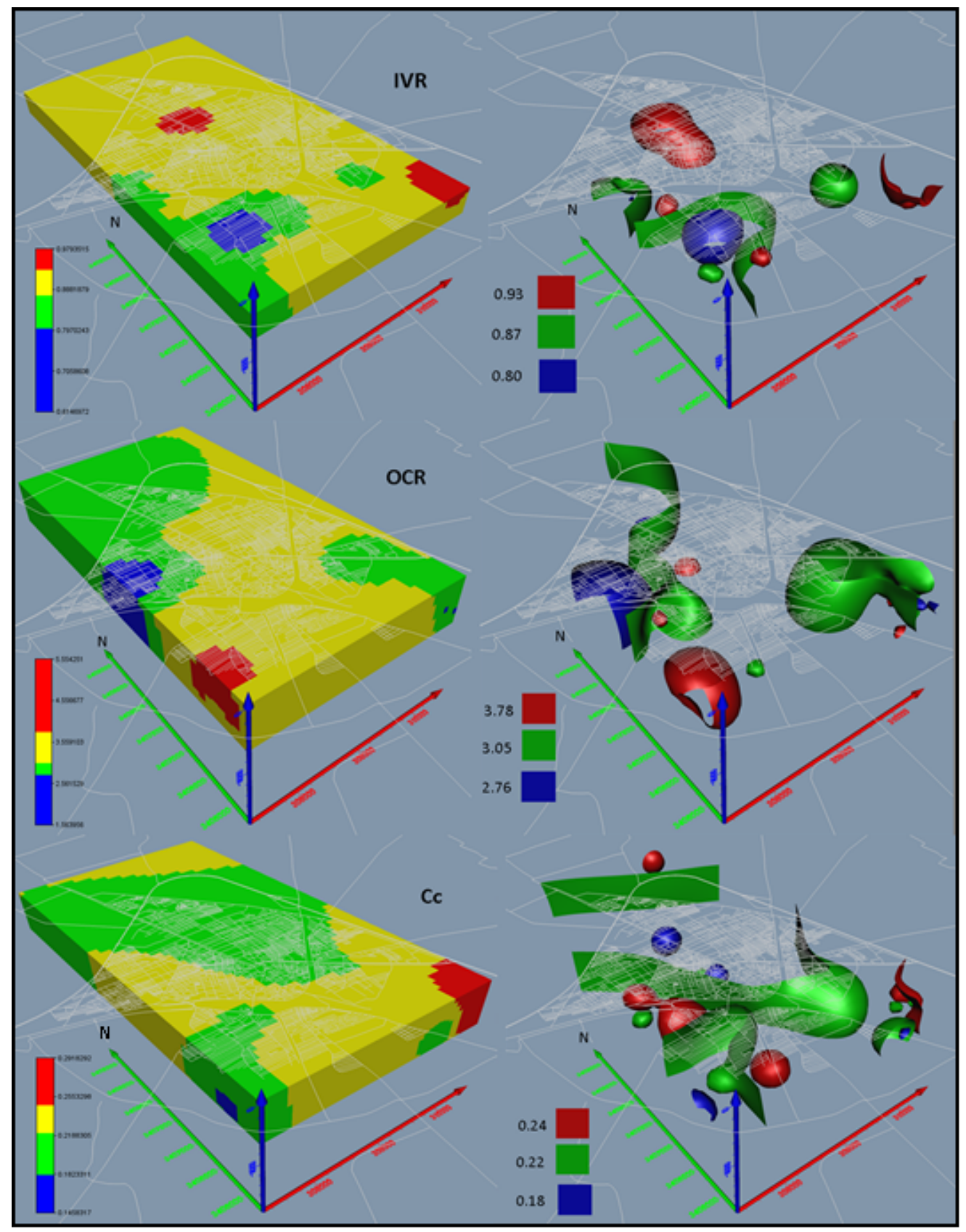

Fig. (8): Consolidation parameters 3D models (left) and iso-surfaces (right) of Tanta City. 


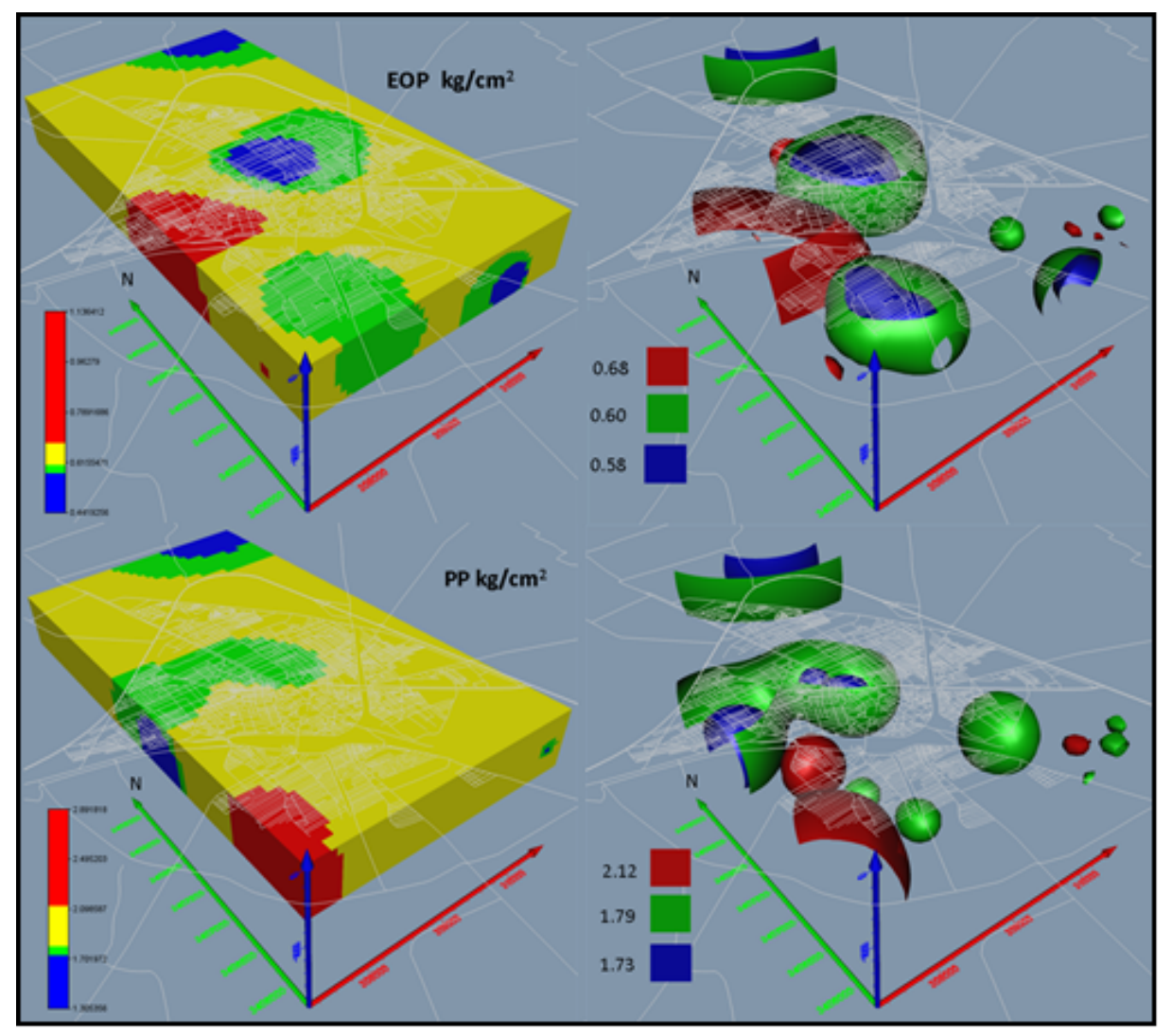

Fig. (8): Continued.

النمذجة الجيولوجية والجيوتقتية التحت سطحية ثلاثية الابعاد لتقييم المخاطر الجيولوجية للتربة النهرية بمنطقة طنطا، مصر، باستخدام

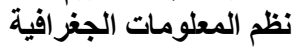

\section{علاء /حد مسعود وسمبير زكي قدح وسارة رجب الغريب}

قسم الجبيولوجيا - كلية العلوم - جامعة طنطا

لقد تم تحليل البيانات الجيولوجية والجيوتقنية التي تم الحصول عليها من 159 بئر منتشرة في منطقة طنطا، مصر وكذلك المعاملات التي تم

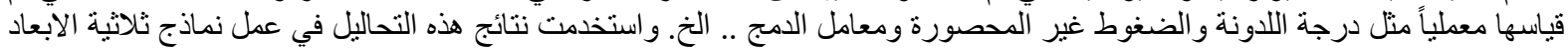

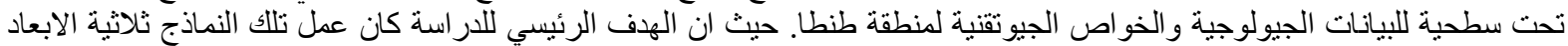

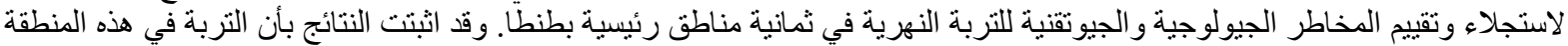

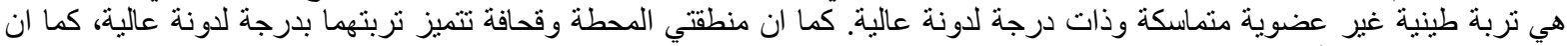

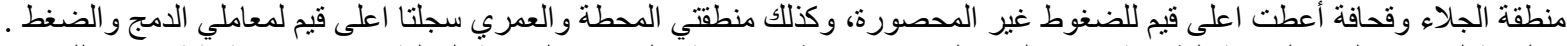

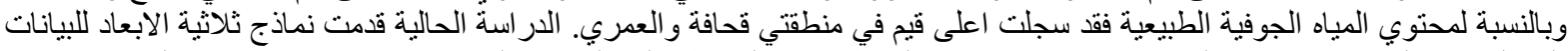
الجيولوجية والجيوتقنية افضت الى نتائج تساعد في تحديد المناطق ذات المخاطر الجيولوجية ولفية والجيوتقنية وتضع امام متخذي القرار مشكلات 
هذا النوع من التربة في المناطق السكنية القائمة حالياً وطرح رؤية للمناطق غير المأهولة و التي تعثبر امتداد ضروري وحتمي للمناطق

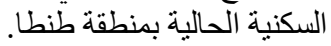

